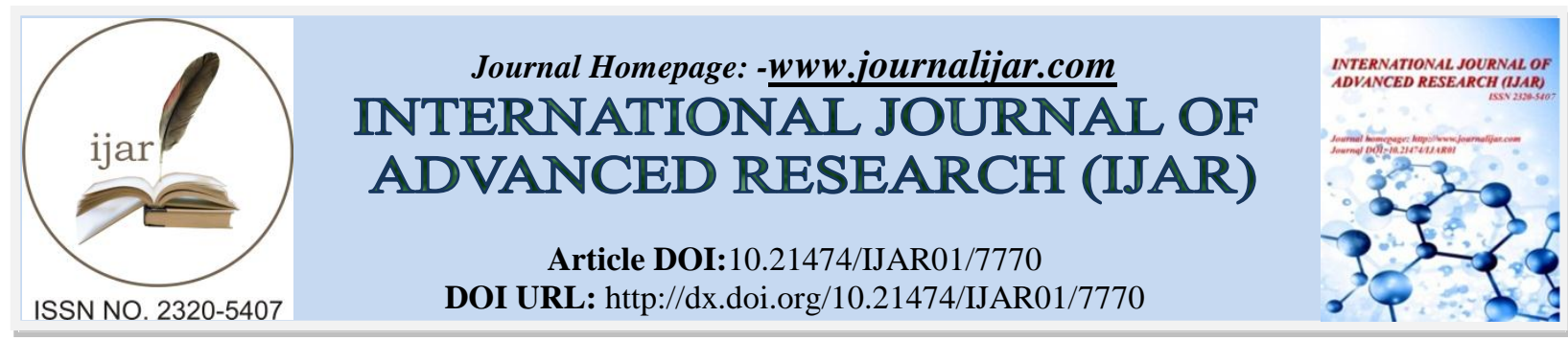

RESEARCH ARTICLE

\title{
NON-JUDICIAL DISPUTE SETTLEMENT IN CRIMINAL CASE: A COMPARATIVE ANALYSIS OF PENAL POLICY IN THE NETHERLANDS AND THE UNITED KINGDOM.
}

\author{
Ahmad Hajar Zunaidi and Nur Basuki Minarno. \\ Law Faculty, Airlangga University, East Java, Indonesia.
}

\section{Manuscript Info}

Manuscript History

Received: 25 July 2018

Final Accepted: 31 August 2018

Published: September 2018

Keywords:-

criminal law, comparative, minor crime, expediency principle, justice.

\begin{abstract}
A minor crime must be resolved by the same mechanism as a serious criminal offense, which is one of the forms of the irony of justice. The problem of the irony of justice often occurs in the Indonesian criminal justice system because it is very ineffective, not in accordance with the principle of fast, simple, and low cost. Penal policies in the Netherlands and United Kingdom have developed a variety of non-judicial criminal case settlement mechanisms for the minor crime. The legal issue analyzed in this paper is the basis of thinking of penal policy that develops a non-judicial criminal case settlement mechanism. The method used is a literature review to make a comparative analysis on the penal policy in the Netherlands and UK to develop the non-judicial criminal case settlement mechanism. The result of the analysis is the basis of thinking of penal policy for developing a non-judicial settlement mechanism criminal case that is to bring about justice through the simplification of the criminal justice system and the application of the expediency principle.
\end{abstract}

Copy Right, IJAR, 2018,. All rights reserved.

\section{Introduction:-}

A minor crime must be resolved with the same mechanism as the serious criminal offense, which is one of the forms of the irony of justice. In order to reduce such problem of justice's irony, some countries have developed a variety of non-judicial criminal case settlement mechanisms for minor cases. Another consideration of the urgency of developing such mechanism is that the criminal justice system in each country is generally only capable of processing a small portion of all criminal offenses. ${ }^{1}$ If a state investigates, prosecutes, adjudicates and penalizes all perpetrators, every stage of the criminal justice system will not be able to handle or process such crimes entirely. Therefore, the police and the public prosecutor who will bring the perpetrator into the criminal justice system shall exercise discretion to determine which cases to proceed or to terminate the prosecution. If the prosecution continues, it will be decided which cases are with the judicial sanctions and which ones are with the extrajudicial sanctions.

The systematic solution to such irony of justice matters is legal policy to developing a non-judicial criminal cases settlement mechanism for minor cases in the Indonesian criminal justice system. ${ }^{2}$ Such implementation rests on the

${ }^{1}$ UN Office on Drugs and Crime, Handbook of Basic Principles and Promising Practices on Alternatives tolmprisonment, UN Publication, New York, 2007, p.14

${ }^{2}$ Legal policy can bee seen as the development of a new vision of the law place and role in the modern life and to form a law-governed state and civic society. For more discusion see Alexander Vasilyevisch Malko, et.all, 'Legal Policy as a Means to Improve Lawmaking Process', in Astra Salvensis, an VI, Numair 11, 2018, p.834. 
regulation of its prosecution discretion by the public prosecutor. Thus, this paper analyzes the legal issue in the basis of thinking of penal policy to develop the non-judicial criminal case settlement mechanism. The analyzes result of this basis of thinking is expected to provide a prescription in the form of vision and new policy direction for developing that settlement mechanism for minor criminal offense cases in Indonesian criminal law.

The analysis on the basis of thinking of penal policy to develop the non-judicial criminal case mechanism settlement is heuristically conducted in the search of relevant legal principles to the nature of the idea, meaning and objective of the non-judicial settlement mechanism for minor cases, with regard to the factual moment, that is the fact of the penal policy for this settlement mechanism. ${ }^{3}$ The results of the searching process indicate that the expediency principle is the main basis of thinking of the penal policy to develop the settlement mechanism for minor criminal offenses. In addition, the other relevant principles are namely the principle of opportunity, the principle of fast, simple, and low cost criminal process, as well as the principle of ultimum remedium.

\section{The Expediency Principle in the Criminal Law of the Netherlands}

The traditional view toward the importance of punishment is to prevent the occurrence of danger or the risk of danger to others, accordingly, actions that are contrary to moral values with no harm to others are not expedient to punish. ${ }^{4}$ Another view holds that 'danger' itself is an inseparable situational concept from the moral value, due to the fact that the concept of 'danger' can be interpreted as all actions violating legitimate rights and interests among others, including their moral, cultural, and political interests. ${ }^{5}$

In addition to that 'dangerous' aspect, an action is expedient to punish when public realizes and approves it for its wrongfulness, its contradiction to the shared values commitment. ${ }^{6}$ Thus, the onset of the public interest is the basis of expediency of an action categorized as a crime (criminalization). At this stage of penal policy (criminalization or decriminalization), the expediency principle plays an important role to prevent such action with more harmful impact to the community rather than when it is not categorized as a crime.

The next important role of the expediency principle is at the stage of implementing the penal policy. When making the decision not to prosecute, the public interests should be truly taken into account. Even though an act has been categorized as a criminal offense, when it is performed in such a manner or under such conditions, its nature can be categorized as a minor crime. Accordingly, the public prosecutor should consider whether the public interest still demands perpetrators to be prosecuted and punished.

Due to the policy to align the enforcement on materials on criminal law with the public needs and also to utilize the limited law enforcement capacity available to work within the principles of effectiveness, the law enforcement in the Netherlands has some degree of freedom to adopt a policy of terminating the prosecution. Such freedom is based on the acceptance of the expediency principle in the Netherlands criminal law. Based on this expediency principle, the basis of the law enforcement is dependent on the main criterion, the public interest, in applying this principle. ${ }^{7}$

In 1926 the expediency principle was included in the Wetbook van Strafvordering (Sv.) in Article 167 Sv. declaring that 'public prosecutors should decide to prosecute when it is an important prosecution based on the results of the investigation. Furthermore, the prosecution can be terminated on the basis of public interest". ${ }^{8}$

\footnotetext{
${ }^{3}$ Sidharta, `Heurestika dan Hermeneutika: Penalaran Hukum Pidana`, in Jufrina Rizal dan Suhariyono AR (editor), Demi Keadilan: Antologi Hukum Pidana dan Sistem Peradilan Pidana: enam dasawarsa Harkristuti Harkrisnowo, Pustaka Kemang, Jakarta, 2016, p.9-10.

${ }^{4}$ See e.g. Joel Feinberg, 'Harmless Wrongdoing inMoral Limits of the Criminal Law, Oxford University Press, 1988.

${ }^{5}$ See e.g. D. N. MacCormick, Legal Right and Social Democracy, 1982, also Andrew Ashworth \& Jeremy Horder, Principles of Criminal Law (Part 2. Criminalization), $7^{\text {th }}$ ed., Oxford University Press, Oxford, 2013, p.6

${ }^{6}$ See e.g. R. A. Duff, Answering for Crime:Responsibility and Liability in The Criminal Law (Legal Theory Today), Hart Publishing, 2000.

${ }^{7}$ Willem Geelhoed, Het Opportuniteitsbeginsel en Hetrecht van de Europese Unie : Een Onderzoek Naar de Betekenis van Strafvorederlijke beleidsvrijheid in de Geeuropeaniseeide rechtsorde, Kluwer, Deventer, 2013,p. 412

${ }^{8}$ Peter J. P. Tak, Methods of Diversion Used By the Prosecution Service in the Netherlands and Other Western European Countries, presentedin the forum International Senior Seminar Visiting Experts` Papers number 135, by United Nations Asia and Far East Institute (UNAFEI) for the Prevention ofCrimes and the Treatment of Offender at January 12 - 16 Februari 2006, resource material series No.74.
} 
The principle of legality rigidly obliges to prosecute all crimes with sufficient evidence, seen as a "traditional paradigm" that has been gradually replaced with a new one during the 17 th century. ${ }^{9}$ Conditions leading to the paradigm shift are because of the immense dysfunction of the criminal justice system, resulting in a very powerful social protest; consequently, a crisis of confidence in law enforcement occurs, as well as the rapid population increase. The Court and the Prosecutor's Office must address these social effect issues and take them into account for its actions in criminal law.

The expediency principle has been interpreted in a "positive sense" with the basic premise that a duty to prosecute is performed only if the public interests desired, so the requirement legitimacy that is the legal order interest and the onset of the requirement legality. Therefore, the prosecution policy of a crime must be directed to enforce the law not only in the rule (wethandhaving) but also in the implementation of the law in general that is to realize legal order (rechtshandhaving). This concept means implementing the expediency principle in a positive sense, in extending the stage from the implementation to the investigation. ${ }^{10}$

The formulation of Article $167 \mathrm{Sr}$. states that "public prosecutors should decide to prosecute when it is considered important based on the results of the investigation. The prosecution can be terminated on the basis of the public interest." This leads to perceiving that the Netherlands accepts the expediency principle in 'a negative sense' meaning that this principle is the basis for terminating the prosecution process. This is different from the UK known to follow the common law tradition with an adversarial prosecution system; hence, the expediency principle is accepted in a "positive sense" meaning that the basis to prosecute is to consider the public interest.

Andrew von Hirsch disagrees with AC't Hart who only focuses his attention on the stage of prosecution, since the expediency principle is on the wider thinking of criminal sanctions. This thought could affect the later stages of criminal proceedings, such as the imposition of criminal sanctions. ${ }^{11}$ The expediency principle not only underlies the discretion of the authority of the public prosecutor in making decisions to prosecute or not, but also acts as a related guide to the prevention and social benefits to prosecute. ${ }^{12}$

This principle argues against the traditional legal principle that it is obliged to prosecute when there is sufficient evidence. ${ }^{13}$ This rigid law enforcement in such conditions leads to adverse social conflicts, and further burdens the resources of the law enforcement system. The expediency principle practically offers the solution, by allowing the public prosecutor to undertake discretionary or non-prosecution conduct based on the degree of the priority.

When it is still necessary to prosecute, the expedient prosecution mechanisms in accordance with the criminal offenses must be applied and should be corresponding to consistent ways with the principles of effective case handling. The objective is to achieve the purpose of punishment, prevention, and restoration in a balanced way, with regard to the condition of criminal offenses. As shown in the application of transaction mechanisms (afdoening buiten process) in the cases of Ballas Nedam, KPMG Accountant NV and SBM Offshore. ${ }^{14}$ Therefore, The expediency principle in the criminal procedure law in the Netherlands is manifested with simplifying the criminal justice system by developing various non-judicial settlement mechanisms for criminal cases, namely transaction or afdoening buitenprocess under Article 74 paragraph (1), paragraph (2), and 74a, 74b, 74c wetbook van strafrecht (Sr.), as well as penal order under Article 257 a-h Wetbook van Strafvordering (Sv.).

\section{The Expediency Principle in the Criminal Law of the United Kingdom}

Different from the Netherlands with its inquisitorial prosecution system, the United Kingdom is a country with an adversarial prosecution system as in the common law tradition accepting the expediency and opportunity principles.

${ }^{9}$ A.C.`t Hart, Criminal Law Policy in Netherland, inJan van Dijk, Dkk, (ed.), Criminal Law in Action: an overview of current issues in western societies, Kluwer Law and Taxation Publishers, Deventer, 1988, p.75.

${ }^{10}$ Ibid.

${ }^{11}$ Andrew von Hirsch, Expediency, Policy and Explicit Norms in Criminal Justice, in Jan van Dijk. Ibid.p.111

${ }^{12}$ Ibid.

${ }^{13}$ See e.g. Wolfgang Naucke, Strafrecht: Eine Einfuhrung, 3rd ed. Metzner Verlag,Frankfurt, 1980, p.168-173.

${ }^{14}$ Report Netherlands Government of Organization for Economic Cooperation and Development (OECD), The Netherlands: Follow-Up to The Phase 3 Report \& Recommendations, May 2015 
This means that the basis to exercise discretionary of the prosecution authority is not only granted to the public prosecutors or senior officials but also is consistent in its system. In fact, the decision to prosecute or not is not exclusively become the responsibility for the public prosecutor. Many decisions to avoid prosecution are made by the police; as a result it is difficult to control and supervise. ${ }^{15}$

From the history of the prosecution system in the UK, it can be observed the consistency of discretion of prosecution authority in its legal system. Initially, a specialized agency to prosecute was not present in this country, prosecutions were also be able to perform by individuals personally or privately, thus raising the issue of efficiency and difficulty to prove the wrongdoing and to punish perpetrators, and often to provoke judges to act actively like public prosecutors, violating the principle of judicial impartiality. ${ }^{16}$

Based on Marian Statutes 1555, Justices of the Peace (JPs) is established as the public prosecutor, elected by the Royal Commission for each county and city with the task of the law enforcement against crimes in the UK. ${ }^{17}$ Each JPs' individual is also with a very important responsibility in the process of terminating the non-judicial settlement for criminal offenses, ordering the suspects' detention, prosecuting to the court, and releasing suspects held in custody on the basis of suspension of proceedings on bail. Moreover, the Police is also responsible for a case prosecution by which they may appoint several experienced local lawyers, as a result, there is no uniformity and certainty for controlling the prosecution policy nationwide. ${ }^{18}$ Not until October 1986, did the Crown Prosecution Service perform its function to prosecute in the UK, as reaction to a series of Police actions violating the sense of justice in which they manipulate evidence and press the suspects, so CPS must review first before the Police prosecute, as regulated in Article 23 paragraph (8) Prosecution of Offenses Act of $1985 .{ }^{19}$

The Attorney General can terminate the ongoing prosecution process usually initiated by private parties when the prosecution is considered as unimportant and in conflict with the interests of the kingdom. ${ }^{20}$ Such authority from him is a procedural instrument that cannot be reviewed by the court. This is based on the theory of the separation of prosecutorial powers, meaning that the executive has the authority to control over the case handling and under the factual circumstances. With more burdens in the criminal justice system, the public prosecutor should prioritize certain prosecutions among several cases. Therefore, based on the common law tradition, the UK prosecution system provides wider space for the application of discretionary authority to prosecute for terminating the case on the basis of the public interest based on the expediency principle. ${ }^{21}$

Under Article 23 of the Criminal Justice Act of 2003, the police and prosecutors may not prosecute a criminal offense when it is assessed as a minor crime by outlining terms and criteria to exercise the discretion of the prosecution authority. The former is to ensure that the perpetrator is guilty indeed and certainly get punished once the prosecution is exercised, because the cautioning letter is actually a plea of guilt that can be recorded by the court. This warning mechanism is used by the police to resolve almost $30 \%$ of all cases reported. ${ }^{22}$

\footnotetext{
${ }^{15}$ See e.g. Despina Kyprianou, Comparative Anaysis of Prosecution Systems (Part II) : The Role of Prosecution Services in Investigation and Prosecution Principles and Policies, p.19, downloaded www.law.gov.cy at October 17, 2011. See alsoJ. Fionda, Public Prosecutors and Discretion: A Comparative Study,Clarendon Press, Oxford, 1995.

${ }^{16}$ Sarah J. Summers, Fair Trials, The European Criminal Procedural Tradition and The European Court of Human Rights, Hart Publishing, Portland, 2007, p.35.

${ }^{17}$ John H. Langbein, `The Origins of Public Prosecution at Common Law`, in American Journal of Legal History, vol.XVII, 1973, p.318.

${ }^{18}$ Jacqueline Hodgson, 'The Democratic Accountability of Prosecutors in England and Wales and France: Independence, discretion and managerialism', in Langer,Maximo, Sklansky, David Alan (eds), Prosecutors and Democracy: A Cross-Nation Study, Cambridge University Press, Cambridge, 2016, p.12.

${ }^{19}$ Erik Luna dan Mariane Wade, 'Prosecutors as Judges`, inWashington and Lee Law Review, vol.67.Issue 4, article 6, January 9, 2010,p.1438

${ }^{20}$ Rebecca Krauss, The Theory of Prosecutorial Discretion in Federal Law: Origin and Developments, in Seton Hall Circuit Review, vol.6, Issue 1, article 1, November 6, 2012, p.2.

${ }^{21}$ Peter J. P. Tak, Op. Cit., p.57.

${ }^{22}$ Ibid.
} 
The UK Government has issued the Code for Crown Prosecutors in 2000 under Article 10 of the Prosecution of Offices Act (POA) of 1985 to regulate the use of non-judicial settlement mechanisms. This code determines the two conditions prior to the prosecution, which must be met, namely, the fulfillment of the evidential test as of the onset of the realistic prospect of conviction of the indictment, and such prosecution may only be exercised when required by the public interest (the public interest test). ${ }^{23}$

The requirements of the public interest test include the perpetrators' offense rate (the role of participation, the planning), the danger to the victim, the public impact. Furthermore, the public prosecutor should notice whether the prosecution is the expediency response for the crime, that is to achieve the purpose of punishment, prevention and restoration, in a balanced manner under criminal conditions, and prosecutions must be in accordance with consistent ways with the principles of effective case handling, such as the adoption of the mechanism of Deferred Prosecution Agreement (DPA) applied by the CPS and Serious Fraud Office (SFO) in the cases of Rolls Royce, Standard Bank, and XYZ Limited. ${ }^{24}$

The other criterion for applying the non-judicial case settlement mechanism is based on the Crime and Disorder Act 1998. Accordingly, the police can terminate the process of criminal procedural law further by issuing a "Cautioning" against adult offenders, and the letter of "Reprimand and Warning" for juvenile offenders. The "Cautioning" to the adult perpetrator is provided by the police when the sufficient evidences present as the basis to prosecute, and the perpetrator acknowledges his or her wrongdoing, and the offender approves the established procedure. In addition, the perpetrator must also meet the followings, old or weak enough, mentally ill, and suffering from some physical or mental illness.

Asas oportunitas sebagai dasar penyelesaian perkara tindak pidana ringan di luar persidangan.

Diskresi penuntutan dipengaruhi oleh dua asas yakni asas legalitas dan asas oportunitas. ${ }^{25}$ Asas legalitas mewajibkan penuntut umum untuk selalu melakukan penuntutan pada setiap perkara pidana, sedangkan asas oportunitas memberikan kebebasan kepada penuntut umum untuk memutuskan kebijakan dalam prioritas penuntutan. Penuntut umum di Belanda dapat tidak melakukan penuntutan suatu perkara jika penuntutan ini tidak menguntungkan dengan berbagai pertimbangan yang sangat sulit untuk mendefinisikannya karena seringkali tergantung pada budaya hukum daerah tertentu, kebijakan pidana nasional, kondisi lokal, keadaan kasusnya sendiri, keadaan korban dan pelaku, namun dapat ditemukan kesamaan alasan penghentian penuntutan secara umum yakni tiadanya bahaya yang nyata bagi tertib hukum dan bagi masyarakat.

Indriyanto Seno Adji berpendapat bahwa asas oportunitas merupakan suatu beleid dari penuntut umum yang memperbolehkan memutuskan untuk menuntut atau tidak menuntut, baik dengan syarat maupun tidak dengan syarat (Belanda, Norwegia, Inggeris, dan negara-negara dengan sistem Anglo Saxon seperti Australia). Kemudian tentang asas legalitas (dalam penuntutan seperti Jerman, Austria, Spanyol), artinya penuntut umum tidak memiliki kewenangan untuk mengesampingkan suatu perkara, karena penganutan asas ini tetap mengharuskan suatu perkara untuk dilimpahkan ke pengadilan, tanpa memiliki suatu sikap eksepsionalitas. ${ }^{26}$

Pelaksanaan asas oportunitas secara positif di Indonesia saat ini belum diatur secara komprehensif karena hanya tersirat ada pada Pasal 82 KUHP yang menentukan bahwa kewenangan penuntutan menjadi gugur disebabkan dibayarnya denda maksimum dan biaya-biaya karena penuntutan telah dimulai atau diserahkannya barang-barang yang ditetapkan untuk dirampas. Dampak belum adanya hukum positif yang mengatur asas oportunitas secara komprehensif maka jaksa penuntut umum harus menuntut semua delik yang terjadi. Padahal penuntutan tersebut masih dilaksanakan berdasarkan hukum pidana materiil warisan kolonial Belanda yang masih bersifat represif dan

${ }^{23}$ Gary Slapper and David Kelly, The English Legal System, fifth edition, Cavendish Publishing Ltd,London, 2001, p.425.

${ }^{24}$ Organisation for Economic Cooperation and Development (OECD), Implementing The OECD Anti-Bribey Convention, Phase 4 Report : United Kingdom, h.75, downloaded www.oecd.or/corruption, March $25,2017$.

25 Tony Paul Marquery, Unity and Diversity of The Public Prosecution Services in Europe, A Study of The Czech, Dutch, French and Polish Systems, University of Groningen, 2008, p.305-306, downloaded www.rug.nl/research/portal. Agusus 27, 2017, 09.30 A.M

${ }^{26}$ Indriyanto Seno Adji, Korupsi, Kebijakan Aparatur Negara \& Hukum Pidana, $2^{\text {nd }}$ edt.,Diadit Media, Jakarta, 2007, p.452-453. 
tidak sesuai dengan nilai-nilai budaya, pandangan hidup, tata susila, dan moral keagamaan serta kepentingan bangsa Indonesia. Mengingat sampai batas tertentu, dapat dikatakan bahwa hukum pidana suatu bangsa merupakan indikasi dari peradaban bangsa tersebut, maka penegakan hukum di Indonesia semakin memprihatinkan dan dapat dinilai merendahkan martabat peradaban bangsa Indonesia karena jauh dari tercapainya tujuan penegakkan hukum pidana.

Upaya untuk mengatasi kondisi demikian, maka menjadi sangat penting untuk dilakukan perbaikan sistem peradilan pidana agar dapat tercipta pelaksanaan peradilan pidana yang patut dan semestinya (behoorlijk strafrechtspleging decently administration of criminal justice), yakni salah satunya adalah melalui upaya mendekatkan tafsiran undang-undang dengan teori dan praktek pelaksanaan hak oportunitas yang dimiliki oleh penuntut umum. ${ }^{27}$ Adanya kesenjangan antara tafsiran undang-undang dengan teori dan praktek pelaksanaan hak oportunitas oleh penuntut umum disinyalir sebagai salah satu penyebab terjadinya ironi keadilan dalam dunia penegakan hukum saat ini.

Asas oportunitas memiliki persamaan dengan asas kelayakan (expediency), karena asas kelayakan yang menjadi dasar keputusan penuntut umum untuk tidak melakukan penuntutan adalah kepentingan publik, begitu pula asas oportunitas yang menjadi dasar kewenangan penuntut umum untuk tidak melakukan penuntutan adalah dengan berbagai pertimbangan yang relevan dengan tujuan pemidanaan yang didalamnya terdapat faktor kepentingan publik. Sedangkan perbedaannya, asas expediency memiliki fungsi yang sangat luas, sebagai pedoman penyusunan kebijakan pidana untuk menentukan tindakan-tindakan apa saja yang patut dipidana, sebagai pedoman pelaksanaan kebijakan pidana atau peraturan perundang-undangan, sampai menjadi pedoman dalam penjatuhan sanksi pidana. Asas expediency tidak hanya mendasari diskresi kewenangan penuntut umum dalam mengambil keputusan untuk menuntut atau tidak menuntut, namun juga sebagai pedoman terkait pada manfaat pencegahan dan manfaat sosial dalam melakukan penuntutan.

Asas oportunitas diterima oleh negara-negara dengan tradisi civil law adalah dimulai oleh Jerman, selanjutnya Belanda juga menerima asas oportunitas dalam sistem hukumnya, sedangkan dalam teori hukum di Indonesia juga menerima asas oportunitas ini dengan perwujudan normanya yakni diberikannya diskresi kepada penuntut umum untuk menolak atau menghentikan penuntutan apabila tidak menguntungkan bagi kepentingan masyarakat. ${ }^{28}$ Sejarah penerapan asas oportunitas di Indonesia dapat ditelusuri sampai dengan adanya Pasal 179 Reglement op de Rechtelijke Organisatie en het beleid der Justitie (RO) Tahun 1848, tapi ada pula pihak yang mengatakan bahwa dengan adanya pasal itu bukan berarti dianut asas oportunitas karena di dalam Pasal 179 RO itu diberikan kewenangan kepada Hooggerechtshof (Mahkamah Agung) untuk, bila mengetahui telah terjadi kealpaan dalam penuntutan kejahatan atau pelanggaran, memberi perintah kepada Pokrol Jenderal (Jaksa Agung), supaya melaporkan tentang kealpaan itu dengan hak memerintahkan agar diadakan penuntutan jika ada alasan-alasan untuk itu. Pendapat tersebut dianut oleh Vonk, dan juga W.L.G. Lemaire yang mengatakan bahwa asas oportunitas ini telah berlaku di Indonesia sebagai hukum yang tidak tertulis, sedangkan pihak yang mengatakan dengan adanya Pasal 179 RO itu dianut asas oportunitas karena pada ayat pertama pasal itu ada frasa "kecuali jika penuntutan oleh Gubernur Jenderal dengan perintah tertulis telah atau akan dicegah". ${ }^{29}$

Asas oportunitas sering dipandang bertentangan dengan asas legalitas dalam sistem penuntutan inquisitorial orthodox yang melarang adanya diskresi penuntutan dan setiap perkara harus dikirim untuk diproses di persidangan untuk menemukan kebenaran yang sesungguhnya. ${ }^{30}$ Pandangan bahwa setiap perkara harus diproses dipersidangan tersebut justru menghasilkan kondisi yang tidak adil karena perkara-perkara minor yang seharusnya dapat diselesaikan dengan mekanisme yang lebih sederhana dan cepat harus diselesaikan dengan mekanisme persidangan yang lama, berbelit, dan biaya tinggi. Berdasarkan pemikiran tentang cara mempertahankan atau memulihkan

${ }^{27}$ Mardjono Reksodiputro, Rekonstruksi Sistem Peradilan Pidana Indonesia, Paper presented in Kuliah Umum Universitas Batanghari, Jambi, April 24, 2010, p. 4.

${ }^{28}$ Markus Dirk Dubber, 'American Plea Bargains, German Lay Judges, and the Crisis of Criminal Procedures `49 Stanford Law Review, 547, 575-76 (1997). See also Robert R. Strang, 'More Adversarial, but not Completely Adversarial : Reformasi of the Indonesian Criminal Procedure Code ', in Fordham International Law Journal, vol.32. Issue 1, 2008, article 13, p.208.

${ }^{29}$ See W.L.G. Lemaire, Het Recht in Indonesia, Hukum Indonesia, a Gravenhage : W. Van Hoeve, 1952, p.149. See also E Bonn Sosrodanukusumo, Tuntutan Pidana, Djakarta : Penerbit Siliwangi, p.266-267. See also Andi Hamzah, Hukum Acara PidanaIndonesia, Sapta Artha Jaya, Jakarta, 1996, p.15-16.

${ }^{30}$ Stephen C. Thamam, 'Legality and Discretion', inEncyclopedia Of Law \& Society : American and Global Perspective, 944,945 (David S. Clark ed., 2007). 
keseimbangan keadilan yang seringkali diformulasikan dengan kalimat treat like cases alike and different cases differently, maka penerapan asas oportunitas dalam suatu sistem hukum harus diterapkan secara berimbang dengan asas legalitas..

Secara yuridis, Indonesia telah mengakui dan menerima adanya asas oportunitas namun dalam aspek negatif (karena bersifat sangat terbatas), hal itu dapat dilihat dari ketentuan Pasal 35 huruf c Undang-Undang Nomor 16 Tahun 2004 tentang Kejaksaan bahwa : "Jaksa Agung mempunyai tugas dan wewenang mengesampingkan perkara demi kepentingan umum". Jika asas oportunitas tersebut diwujudkan dalam peraturan perundang-undangan di Indonesia, seharusnya tidak hanya dari aspek negatif tapi juga dari aspek positifnya juga yakni dalam bentuk diberlakukannya mekanisme transaksi atau afdoening buiten proces baik dalam bentuk submissie ataupun compositie, maka jaksa dapat mempergunakan hati nuraninya dalam menangani perkara berdasarkan asas subsidiaritas. Pada sisi lain, jika diberlakukannya mekanisme transaksi atau afdoening buiten proces dalam hukum acara pidana kita maka akan menghidupkan asas subsidiaritas dalam sistem hukum pidana Indonesia.

Asas Peradilan Cepat, sederhana, dan biaya ringan sebagai dasar penyelesaian perkara tindak pidana ringan di luar persidangan.

Teori hukum pidana membedakan antara hukum pidana materiil (substantif) dan hukum pidana formil (acara). Hukum pidana materiil antara lain mengatur syarat-syarat suatu perbuatan bisa disebut tindak pidana, apa unsurunsur tindak pidana, siapa subyek tindak pidana tersebut, keadaan-keadaan bagaimana yang menjadikan suatu perbuatan dilarang, ketentuan-ketentuan yang dapat membebaskan pelaku suatu perbuatan dan sebagainya. ${ }^{31}$ Hukum pidana formil (hukum acara pidana) mengatur tentang bagaimana negara melalui alat-alatnya melaksanakan haknya untuk memidana dan menjatuhkan pidana. Asas peradilan cepat, sederhana, dan biaya ringan tersebut berada dalam konteks hukum pidana formil.

Pasal 9 ayat (3) ICCPR (International Covenant on Civil and Political Rights) menyatakan bahwa anyone arrested or detained on a criminal charge shall be brought promptly before a judge or other officer authorized by law to exercise judicial power and shall be entitled to trial within a reasonable time or to release. Persoalan di Indonesia saat ini adalah tidak adanya judicial review atau pengujian hakim terhadap keabsahan tindakan penahanan yang dilakukan pada tahap penyidikan selama 20 (dua puluh) hari sehingga dinilai sebagai pelanggaran terhadap Pasal 9 ICCPR. Oleh karena itu, tersangka dalam sistem peradilan pidana di Indonesia, yang belum tentu terbukti kesalahannya, pasti merasakan penderitaan yang sangat panjang akibat masa penahanan selama dua puluh hari, yang juga belum pasti keabsahan tindakan penahanan yang dilakukan oleh penyidik terhadap dirinya tersebut.

Selain persoalan tidak adanya uji keabsahan terhadap tindakan penahanan yang dilakukan pada tahap penyidikan, pelanggaran terhadap Pasal 9 ayat (3) ICCPR juga terjadi karena masa penahanan 20 (dua puluh) hari sebelum sidang tersebut dinilai tidak sesuai dengan standart kecepatan masa penahanan pre trial yang diatur dalam Pasal 9 ayat (3) ICCPR sebagaimana rekomendasi U.N. Human Rights Council, Special Rappourteur on Torture and Other Cruel, Inhuman or Degrading Treatment or Punishment. ${ }^{32}$

Asas peradilan cepat, sederhana, dan biaya ringan telah dirumuskan dalam Pasal 4 ayat (2) Undang-Undang Nomor 4 Tahun 2004 tentang Kekuasaan Kehakiman yang menyebutkan : "Peradilan dilakukan dengan sederhana, cepat , dan biaya ringan.”. Penjelasan Pasal 4 ayat (2)menyebutkan bahwa ketentuan ini dimaksudkan untuk memenuhi harapan para pencari keadilan, dan yang dimaksud dengan "sederhana" adalah pemeriksaan dan penyelesaian perkara dilakukan dengan acara yang efisien dan efektif, sedangkan yang dimaksud dengan "biaya ringan" adalah biaya perkara yang dapat terpikul oleh rakyat. Namun demikian, dalam pemeriksaan dan penyelesaian perkara tidak mengorbankan ketelitian dalam mencari kebenaran dan keadilan. Bahkan asas ini juga telah dirumuskan dalam Pasal 4 ayat (2) Undang-Undang Nomor 14 Tahun 1970 tentang Pokok-Pokok Kekuasaan Kehakiman yang menyatakan bahwa pelaksanaan penegakan hukum di Indonesia harus sesuai dengan asas cepat, sederhana, dan biaya ringan

\footnotetext{
${ }^{31}$ Topo Santoso, Menggagas Hukum Pidana Islam, Penerapan Syariat Islam Dalam Konteks Modernitas, cet.2,Asy Syaamil Press \& Grafika,Bandung, 2001, h.22.

${ }^{32}$ U.N. Human Rights Council, Special Rappourteur on Torture and Other Cruel, Inhuman or Degrading Treatment or Punishment, Promotion and Protection of All Human Rights, Civil, Political, Economic, Social and Cultural Rigths, Including The Right to Development : Mission to Indonesia 20, downloaded U.N.Doc.A/HRC/7/3/Add.7 (March 10, 2008).
} 
Asas peradilan cepat, sederhana, dan biaya ringan juga telah diakui dalam KUHAP, sebagaimana disebutkan dalam bagian Penjelasan Umum KUHAP. Meskipun secara positif telah dirumuskan dalam Undang-Undang Nomor 14 Tahun 1970, tapi pada prakteknya menunjukan kenyataan yang tidak selaras, karena pada tahun 1981, Johanes Badar telah mengalami penahanan selama sembilan tahun tanpa ada penyelesaian proses persidangan. Akhirnya Kejaksaan dan Pengadilan saling lempar kesalahan dan cuci tangan. ${ }^{33}$

M. Yahya Harahap menerangkan, misalkan Pasal 50 KUHAP yang mengatur bahwa tersangka atau terdakwa berhak "segera" mendapatkan pemeriksaan dari penyidik, dan "segera" diajukan kepada penuntut umum oleh penyidik. Terdakwa juga berhak "segera" diajukan ke pengadilan oleh penuntut umum, dan berhak pula untuk "segera" diadili oleh pengadilan, namun KUHAP sama sekali tidak mengatur sanksi atas pelanggaran terhadap hak tersangka atau terdakwa ini.

Selain Pasal 50 KUHAP tersebut, masih ada ketentuan Pasal 102 ayat (1) KUHAP dan Pasal 106 KUHAP yang menentukan bahwa penyelidik dan penyidik yang menerima laporan atau pengaduan tentang terjadinya suatu peristiwa yang patut diduga merupakan tindak pidana wajib "segera" melakukan tindakan penyelidikan dan penyidikan yang diperlukan. Namun sekali lagi KUHAP tidak mengatur sanksi atas pelanggaran ketentuan ini, yakni jika penyelidik atau penyidik terlambat melakukan penyelidikan atau penyidikan berpotensi merugikan korban tindak pidana, karena rusaknya atau hilangnya alat-alat bukti sehingga mempersulit pembuktian.

Begitu pula Pasal 107 ayat (3), Pasal 110, Pasal 138, dan Pasal 140 ayat (1) KUHAP yang mengatur tentang hubungan penuntut umum dan penyidik, yang seringkali mendapatkan kritik dari banyak kalangan, juga dirumuskan dengan kata "segera" dan "secepatnya" . Namun KUHAP juga tidak mengatur sanksi atas pelanggaran jika terjadi keterlambatan-keterlambatan yang dilakukan oleh penyidik maupun penuntut umum, yang dapat merugikan kepentingan dan hak tersangka atau terdakwa.

Asas Ultimum Remedium sebagai dasar penyelesaian perkara tindak pidana ringan di luar persidangan.

Hukum pidana merupakan mekanisme yang mencela dan mencegah tindak pidana, namun sebenarnya masih ada mekanisme lain yakni moralitas dan kebiasaan sosial, dan tekanan sesama sahabat atau saudara yang juga dapat menjadi sumber kontrol informal tindakan manusia. ${ }^{34}$ Selain hukum pidana, sebenarnya masih ada hukum administrasi dan hukum perdata yang juga sama-sama diberlakukan untuk mengatur tindakan manusia, sehingga pemikiran ini dapat ditemukan dasarnya pada pemikiran Jeremy Bentham yang menyatakan agar tidak menggunakan hukum pidana, ketika pidana itu terasa tidak efisien, ketika pidana tidak mampu mencegah atau ketika pencegahan tersebut telah dapat dilakukan tanpa adanya pidana. ${ }^{35}$

Pentingnya asas ultimum remedium dapat ditemukan keselarasannya dengan perkembangan teori deterrence dalam tujuan pemidanaan. Tujuan pemidanaan memang bervariasi namun secara umum dapat dikelompokkan menjadi incapacitation, punishment, deterrence, rehabilitation, dan restorative. Teori deterrence pada intinya adalah pemidanaan itu dilakukan supaya ada efek mencegah orang lain melakukan tindak pidana dengan dua cara. ${ }^{36}$ Pertama, meningkatkan kepastian pemidanaan sehingga orang lain yang akan melakukan tindak pidana akan tercegah karena ketakutan terhadap dampak yang akan terjadi. Kedua, meningkatkan beratnya sanksi pidana sehingga orang lain yang akan melakukan tindak pidana akan tercegah dengan mempertimbangkan bahwa sanksi pidana yang diterimanya lebih merugikan dari keuntungan tindak pidananya.

\footnotetext{
${ }^{33}$ Tempo No.28, Tahun XI, 12 September 1981,h.66 sebagaimana dikutip dalam M. Yahya Harahap, Pembahasan Permasalahan Dan Penerapan KUHAP, Penyidikan dan Penuntutan, edisi kedua, Sinar Grafika, Jakarta, 2005,h.52-53.

${ }^{34}$ Andrew Ashworth \& Jeremy Horder, Principles Of Criminal Law (Part 2. Criminalization), $7^{\text {th }}$ ed., Oxford University Press, Oxford, 2013p.9.

35 Jeremy Bentham, An Introduction to The Principles of Morals and Legislation, (C2010-2015, Jonathan Bennett, chapter 13, h.92-96 downloadedwww.earlymoderntexts.com Agustus 22, 2017, 11.37 AM..

${ }^{36}$ Valerie Wright, Deterrence in Criminal Justice : Evaluating Certainty vs. Severity of Punishment, Research Report The Sentencing Project :Research and Advocacy for Reform, Washington, DC., 2010, p.2, downloadedwww.sentencingproject.org. July 24, 2017, 10.30 AM.
} 
Persoalan teori deterrence adalah asumsi efek mencegah seringkali tidak sesuai dengan kenyataan karena berbagai penelitian menunjukkan bahwa pelaku tindak pidana seringkali dalam kondisi tidak dapat mempertimbangkan dengan baik dampak dari tindak pidananya sehingga peningkatan beratnya sanksi pidana tidak dapat meningkatkan efek mencegah. ${ }^{37}$ Oleh karena itu, yang dibutuhkan adalah adanya peningkatan kepastian bahwa setiap tindak pidana mendapatkan sanksi pidananya, bukan peningkat beratnya sanksi pidana yang dijatuhkan.

Berdasarkan hasil beberapa penelitian tersebut bahwa kepastian adanya sanksi lebih memiliki efek mencegah daripada peningkatan beratnya sanksi, maka yang dibutuhkan adalah mekanisme penuntutan yang cepat dan sederhana, dan tidak membutuhkan mekanisme penuntutan yang berbelit dan lama untuk menjatuhkan sanksi pidana yang berat. Mekanisme penuntutan yang cepat dan sederhana tersebut sesuai untuk menjatuhkan sanksi pidana yang ringan, yang telah dikembangkan oleh Belanda yakni dengan mekanisme transaction. Manfaat lain menggunakan mekanisme penuntutan yang sederhana dan cepat tersebut adalah meringankan beban penegak hukum agar mereka bisa fokus pada perkara-perkara yang berat.

Mekanisme transaction adalah kesepakatan seorang tersangka atau terdakwa tindak pidana minor untuk menerima sejumlah sanksi pidana dan/atau syarat-syarat tertentu dari Penuntut Umum yang sangat mungkin akan diterimanya jika perkaranya disidangkan. Tersangka atau terdakwa boleh menolak tawaran transaksi tersebut, sehingga ia mengikuti persidangan. Satu keuntungan untuk tersangka atau terdakwa yang menerima tawaran transaksi adalah tidak ada pencatatan terhadap kejahatanya, karena berdasarkan prinsip bahwa hakimlah yang berwenang menentukan kesalahan seseorang. Itulah satu perbedaanya dari plea bargaining, meskipun transaksi berfungsi yang mirip dengan plea bargaining. ${ }^{38}$

Manfaat mekanisme transaksi bagi sistem hukum di Belanda adalah sejak sekitar lima puluh tahun setelah Perang Dunia II sistem hukum pidana Belanda telah dikenal sangat humanis dan liberal jika dibandingkan dengan sesama negara Eropa. ${ }^{39}$ Belanda adalah negara yang paling toleran dalam kebijakan hukum pidananya sehingga yang diperkuat adalah pengembangan organisasi sosial yang berdasarkan keagamaan untuk turut serta dalam menangani persoalan masyarakat, sehingga jumlah penghuni penjara di Belanda adalah yang paling rendah. ${ }^{40}$ Berbeda dari Belanda, sampai awal abad 21, Inggris justru dipandang sebagai salah satu negara dengan sistem hukum pidananya yang sangat kejam. ${ }^{41}$ Sampai akhir tahun 2006, banyak hakim dan penegak hukum lainnya memprihatinkan sistem hukum pidana di Inggris yang menjadi sangat berat karena bertambahnya kebijakan kriminalisasi perbuatan dan melemahnya hak-hak prosedural tahanan. ${ }^{42}$

\section{Conclusions}

Based on the comparative analysis on penal policy in the Netherlands and UK to develop non-judicial criminal case settlement mechanism, this study concludes that the basis of thinking of penal policy for developing a non-judicial criminal case settlement mechanism is to bring about justice through the simplification of the criminal justice system and the application of the expediency principle. It is different from the Indonesian criminal justice system because it is very inefficient, not in accordance with the fast, simple, and low cost of legal principles. This study suggests a solution that is the simplification of the criminal justice system and the application of the expediency principle,

\footnotetext{
${ }^{37}$ See Michael Tonry, 'Learning from the Limitation of Deterrence Research', in Crime and Justice : A. Review of Research, ed.Michael Tonry, the University of Chicago Press, 2008, See also Kirk R. Williams, Jack P. Gibbs, and Maynard L. Erickson, 'Public Knowledge of Statutory Penalties : The Extent and Basis of Accurate Perception ', inPacific Sociological Review, 23 (1), 1980. See also Andrew von Hirsch, Anthony Bottoms, Elizabeth Burney, \& P-O Wikstrom, Criminal Deterrence and Sentence Severity: An Anlysis of Recent Research, Hart Publishing, Oxford, 1999.

${ }^{38}$ See Michael Tonry \& Catrien Bijleveld, 'Crime, Criminal Justice, and Criminology in The Netherlands', inCrime \& Justice, vol.35, issue , 2007, p.9.

${ }^{39}$ See David Downes, Contrast in Tolerance: Post-War Penal Policies in Ntherlands and England and Wales, Clarendon Press, Oxford, 1988.

${ }^{40}$ See Rob Allen, Reducing The Use of Imprisonment, What Can We Learn From Europe?, ResearchReport by Criminal Justice Alliance, London, 2012, p.11.

${ }^{41}$ See David Downes,' Visions of Penal Control in The Netherlands', in Crime and Justice : A Review Research, vol.36, ed. Michael Tonry, University of Chicago Press, Chicago, 2007.

${ }^{42}$ Pieter Ippel \& Susanne Heeger, Sprekend de rechbank (Court Voice), University of Utrech, Utrecht, 2006, sebagaimana dikutip Ibid.
} 
namely requiring public prosecutors to highly consider the public interest (public interest test) in determining to implement a non-judicial criminal case settlement mechanism so that law enforcement resources become more focused on handling more serious cases. 